\section{Urea Nitrogen Uptake by Citrus Leaves}

\author{
B.R. Bondada ${ }^{1}$, J.P. Syvertsen, and L.G. Albrigo \\ University of Florida, Citrus Research and Education Center, 700 Experiment \\ Station Road, Lake Alfred, FL 33850
}

Additional index words. ${ }^{15} \mathrm{~N}$-urea, cuticle, epicuticular wax, leaf age, Triazone-urea, Unocalplus urea

\begin{abstract}
Foliar-applied urea nitrogen (N) has potential to become an important component in fertilizer programs for citrus in Florida and other citrus growing areas as it can reduce nitrate leaching into ground water. We evaluated seasonal absorption characteristics of three urea formulations, Triazone-urea, liquid urea, and spray grade urea by citrus leaves that were from 2 weeks to 6 months old. The effect of leaf age on ${ }^{15} \mathrm{~N}$ absorption by $\mathrm{N}$-deficient and $\mathrm{N}$-sufficient leaves, together with urea absorption over an eight-week period were studied using greenhouse-grown and field-grown plants. All foliar $N$ applications were based on a recommended rate of $34 \mathrm{~kg}$ N/ha in $469 \mathrm{~L}$ of water. In the field studies, leaf $\mathbf{N}$ was increased similarly by the three urea formulations one week after three weekly applications. Young leaves $(0.25$ month and 1 month old) absorbed a greater percentage of $N$ than the older leaves ( 3 month and 6 month old). Epicuticular wax concentration increased and ${ }^{15} \mathrm{~N}$ absorption declined with leaf age. Nitrogen deficient leaves $(1.80 \% \mathrm{~N})$ had greater wax concentration and lower $N$ absorption than $\mathrm{N}$ sufficient leaves $(2.60 \% \mathrm{~N})$. Four to 8 weeks after urea applications, Triazone-urea sprayed leaves had significantly greater leaf $\mathbf{N}$ concentration than leaves sprayed with liquid urea or nonsprayed control leaves. The greenhouse studies revealed that the ${ }^{15} \mathrm{~N}$ absorption was greater through abaxial leaf surfaces than through adaxial surfaces regardless of leaf $\mathrm{N}$ level and application time. Applying foliar ${ }^{15} \mathrm{~N}$-urea during night $\left(2000 \mathrm{HR}\right.$ to $2200 \mathrm{HR}$ ) resulted in greater absorption of ${ }^{15} \mathrm{~N}$ than in the morning $(0800$ $\mathrm{HR}$ to $1000 \mathrm{HR}$ ) or afternoon (1200 HR to $1400 \mathrm{HR})$. It is clear that maximum $\mathrm{N}$ absorption from foliar urea sprays occurred at night through the abaxial surfaces of young leaves with sufficient $\mathrm{N}$. Triazone-urea acted as a slow-release $\mathrm{N}$ source that could be exploited in supplying $\mathbf{N}$ over an extended period of time.
\end{abstract}

Nitrates from soil nitrogen $(\mathrm{N})$ fertilization continue to be a potential source of contamination of groundwater in many agricultural areas (Mackay and Smith, 1990; van der Voet et al., 1996), including Florida (Riotte, 1994). Foliar applications of $\mathrm{N}$ have been suggested as an alternative to soil fertilization (Khemira et al., 1998) to decrease the potential of nitrate leaching (Council for Agricultural Science and Technology, 1985). Urea has been considered the most suitable form of foliar N (Swietlik and Faust, 1984) because of its unique physicochemical properties, including nonpolarity, rapid absorption, low phytotoxicity, and high solubility in both oil and water (Knoche et al., 1994; Wittwer et al., 1963; Yamada et al., 1965). Urea can also enhance the absorption of

Received for publication 15 May 2000. Accepted for publication 25 Jan. 2001. Florida Agricultural Experiment Station Journal Series No. R-07574. We thank A.K. Alva for allowing us to conduct ${ }^{15} \mathrm{~N}$ studies in his experimental plots. This research was partially supported by Florida Citrus Production Research Advisory Council. Use of a specific product in this research is not an endorsement of said product. The cost of publishing this paper was defrayed in part by the payment of page charges. Under postal regulations, this paper therefore must be hereby marked advertisement solely to indicate this fact.

'Present address: Univ. of Florida, Dept. of Soil and Water Science, 2169 McCarty Hall, P.O. Box 110290, Gainesville, FL 32611-0290. other foliar-applied chemicals (Bowman and Paul, 1992; Weinbaum, 1988; Yamada et al., 1965).

Citrus production has been maintained by applying 3-6 foliar applications of urea per year implying that $16 \%$ to $33 \%$ of the annual requirement of citrus could be supplied with a single foliar application (Embleton and Jones, 1974). Impey and Jones (1960) calculated that $70 \%$ to $80 \%$ of a $5 \%$ (23.3 g N/liter) urea solution was absorbed by the abaxial surface of young and old 'Washington' navel leaves within 24 h. Ali and Lovatt (1994) demonstrated that a properly timed winter application of low-biuret foliar urea could increase yield of 'Washington' navel oranges. Up to $57 \%$ of the applied ${ }^{15} \mathrm{~N}$ urea $(1.77 \% \mathrm{~N})$ penetrated citrus leaves within $48 \mathrm{~h}$ (Lea-Cox and Syvertsen, 1995), but high rates of foliarapplied urea can cause leaf burn (RomeroAranda and Syvertsen, 1995). Urea uptake by young citrus leaves can be up to 6-fold greater than uptake by old leaves (Lea-Cox and Syvertsen, 1995). We hypothesized that such differences could be attributed to increases in epicuticular wax concentrations as leaves aged.

Triazone-urea is a heterocyclic organic $\mathrm{N}$ compound which has been reported to remain on the leaf surface much longer than conventional urea nitrogen and act as a slow release (2-3 weeks) source of N (Clapp et al., 1991). Previous foliar $N$ studies in citrus mostly used conventional urea as the source of N (e.g., Impey and Jones, 1960). The absorption characteristics of different urea formulations by citrus leaves is not clearly understood. The objectives of this study were to: 1) to evaluate short-term and long-term $\mathrm{N}$ absorption from different urea formulations by leaves of different ages during summer and fall;2) to quantify effects of leaf $\mathrm{N}$ concentration, leaf age, and epicuticular wax concentration on ${ }^{15} \mathrm{~N}$ urea absorption; and 3) to compare ${ }^{15} \mathrm{~N}$-urea absorption through adaxial and abaxial leaf surfaces after applying urea at different times of day. The results of these studies would aid in the selection of the best urea formulation suitable for foliar fertilization in citrus.

\section{Materials and Methods}

Experiment 1. Field study of leaf age and urea formulation. Five similar 10-year-old 'Duncan' grapefruit (Citrus paradisi Macf.) trees on rough lemon (C. jambhiri Lush) rootstock growing in central Florida were selected to study the effects of leaf age and urea formulation on seasonal leaf N concentration. Standard horticultural practices including soil fertilization continued through out the 2-year duration of this study to maintain healthy trees. During fall and summer leaf flush periods, leaves of different ages, 0.25-month-old, ('feather' flush), 1-month-old, (recently fully expanded leaves), and 3-or 6-month-old leaves (spring or summer leaves) were identified by leaf size and branch position. There were 5 single-tree replications with each tree having all four leaf-age classes on different branches. Three urea formulations, liquid Triazone-urea ( $28 \%$ N; Tersenderlo-Kerley, Phoenix, Ariz.), a heterocyclic organic $\mathrm{N}$ compound (Stetrahydrotriazone; Clapp et al., 1991); liquid urea $(<0.25 \%$ biuret, $20 \% \mathrm{~N}$; Unocal Corp., Brea, CA) and spray grade urea (SGU, $46 \% \mathrm{~N}$, pellitized, $0.02 \%$ to $0.05 \%$ Biuret) were tested. Solutions were sprayed onto branches with 6 to 8 leaves in each leaf-age class of the 5 replicate trees at the rate of $34 \mathrm{~kg} \cdot \mathrm{ha}^{-1} \mathrm{~N}$ in 469 $\mathrm{L}$ of water plus $0.05 \% \mathrm{v} / \mathrm{v}$ Triton-X77 as a surfactant and compared to a nonsprayed control. Leaves were sprayed once a week to run off on both leaf surfaces using a hand sprayer for 3 weeks. All applications were made between $0830 \mathrm{HR}$ to $1000 \mathrm{HR}$ and individual branches were temporarily shielded with plastic bags to prevent contact with over spray from subsequent spray treatments. No phytotoxicity symptoms were observed. Seven days after the third application, six leaves from each branch in each of the four leaf-age classes from the five replicate trees (30 leaves per treatment) were put into plastic bags and immediately brought to the laboratory. The leaves were then washed with distilled water to remove any residual nitrogen from the leaf surface and oven dried at $70^{\circ} \mathrm{C}$ for $48 \mathrm{~h}$. The dried leaf tissue was ground to a powder and analyzed for total $\mathrm{N}$ using semi-micro-Kjeldahl method. The six leaves from each replication in each leaf ageclass were pooled for $\mathrm{N}$ analysis.

This study was repeated four times, in Fall 1994, Summer 1995, Summer 1996, and Fall 
1996, on the same trees, but using different branches. All data were analyzed using four urea treatments (includes control) $\times$ four leaf ages $\times$ two seasons factorial analysis of variance (ANOVA) and Duncan's multiple range test at $P \leq 0.05$ with five replications.

Experiment 2. Field study of leaf age, $N$ status, epicuticularwax, and ${ }^{15} \mathrm{~N}$-urea absorption. As part of an ongoing $\mathrm{N}$ rate experiment, four 2-year-old 'Hamlin' orange (Citrus sinensis L.) trees on 'Swingle Citrumelo' (Citrus paradisi $\mathrm{x}$ Poncirus trifoliata) rootstock were grown without nitrogen fertilizer ( $\mathrm{N}$ deficient) on a Candler fine sand in Central Florida. Another four adjacent 'Hamlin' orange trees on 'Swingle Citrumelo' received the recommended rate of $218 \mathrm{~g} \mathrm{~N} /$ tree/year (N sufficient) (Tucker et al., 1995). All trees were well irrigated. Four leaf age classes, 0.25-, 1-, 3-, and 6-month-old leaves, were treated with ${ }^{15} \mathrm{~N}$-urea (conventional; ICON, Naperville, Ill., 5\% atom excess ${ }^{15} \mathrm{~N}$ urea in a fine crystalline form) on the four tree replications in each $\mathrm{N}$ level. Each tree had all four leaf ages on different branches. To ensure leaves were treated with identical volumes of the ${ }^{15} \mathrm{~N}$ solution, the technique of Cook and Boynton (1952) and Zhu (1989) was adopted which involved brushing the ${ }^{15} \mathrm{~N}$-urea solution onto both surfaces of the leaves using a small camel hair brush. Urea solution containing $6 \mathrm{mg}{ }^{15} \mathrm{~N}$ urea per $100 \mu \mathrm{L}$ of water (2.76 mg N per leaf) was applied to each leaf. The ${ }^{15} \mathrm{~N}$ solution was first brushed onto the adaxial surface followed by the abaxial surface until the entire $100 \mu \mathrm{L}$ was on the leaf. The drying time per leaf was $\approx 3-4$ min. No surfactant was added to the ${ }^{15} \mathrm{~N}$ urea solution as urea has some surfactant properties (Yamada et al., 1965). The treated leaves were removed one week after ${ }^{15} \mathrm{~N}$ application and surface cleaned with $5 \%(\mathrm{w} / \mathrm{v})$ cellulose acetate solution to remove any residual ${ }^{15} \mathrm{~N}$ from leaf surface (Lea-Cox and Syvertsen, 1995). The leaves were dipped in cellulose acetate solution for 5-10 s and allowed to dry in a fume hood. The cellulose acetate film was peeled away from the leaf surface, the leaves were oven dried at $65{ }^{\circ} \mathrm{C}$ and ground to a powder form for ${ }^{15} \mathrm{~N}$ analysis.

Extraction of epicuticular waxes. The wax content was determined on two duplicate leaves from each leaf-age class from the four single tree replicates, using a chloroform-gravimetric method (Bondada, 1994). The ${ }^{15} \mathrm{~N}$ and epicuticular wax data were analyzed using a four age $\times$ two $\mathrm{N}$ levels factorial ANOVA and Duncan's multiple range test (DMRT) at $P<0.05$ with four single tree replications per treatment. Potential relationships between ${ }^{15} \mathrm{~N}$ absorption and epicuticular wax concentration were investigated using linear regression analysis.

Isolation of cuticles. Two leaves from each of four replicate trees in each leaf-age group were sampled to determine cuticle weight. Using a cork borer $(3.3 \mathrm{~cm}$ diameter $)$, leaf disks were punched out from mid-laminar area and cuticles were isolated by decomposing the pectic layer beneath the cuticle using pectinase enzyme (Orgell, 1955). After 2 to 3 days, the disks were transferred into water and stirred gently to separate the cuticles from other tissue debris. Cuticle disks were washed gently by several changes of distilled water, air dried and weighed. Cuticle weights were tested for significant differences $(P<0.05)$ using a four ages $\times$ two $N$ levels $\times$ two surfaces factorial ANOVA with four replicate using DMRT to separate the means.

Experiment 3. Greenhouse study of diurnal ${ }^{15} \mathrm{~N}$ absorption by adaxial, abaxial, and both surfaces of the leaves. Fifty, 1-year-old 'Cleopatra mandarin' (Citrus reticulata Blanco) seedlings were grown in $2.3 \mathrm{~L}$ pots of Candler fine sand in an unshaded glasshouse with maximum daily photosynthetic photon flux $(P P F)$ of $1200 \mu \mathrm{mol} \cdot \mathrm{m}^{-2} \cdot \mathrm{s}^{-1}$ under natural photoperiods. Maximum/minimum temperatures in the glasshouse were $33 / 23{ }^{\circ} \mathrm{C}$ and diurnal minimum/maximum relative humidity ranged from $30 \%$ to $100 \%$ during the course of the study. Seedlings were well watered but not fertilized in order to allow the seedlings to become $\mathrm{N}$ deficient. Once yellowing of leaves was observed, 25 seedlings were left unfertilized ( $\mathrm{N}$ deficient) and 25 seedlings were fertilized once every two weeks (biweekly) using 3.2 gram N/week supplied from $20 \mathrm{~N}-20 \mathrm{P}-20 \mathrm{~K}$ in $250 \mathrm{~mL}$ of water to allow them to become $\mathrm{N}$ sufficient. All plants were kept well-watered between the weekly fertilizations. There were five foliar ${ }^{15} \mathrm{~N}$-urea treatments, each applied to 2month-old leaves on 5 replicate seedlings. Treatments were: 1$)^{15} \mathrm{~N}$ application on adaxial and abaxial leaf surfaces of two separate leaves between $0800 \mathrm{HR}$ to $1000 \mathrm{HR} ; 2$ ) ${ }^{15} \mathrm{~N}$ application on adaxial and abaxial surfaces of two separate leaves between $2000 \mathrm{HR}$ to 2200 $\mathrm{HR}$; 3) ${ }^{15} \mathrm{~N}$ application on both surfaces of a single leaf between $0800 \mathrm{HR}$ to $1000 \mathrm{HR}$; 4) between $1200 \mathrm{HR}$ to $1400 \mathrm{HR}$; or 5) between $2000 \mathrm{HR}$ to $2200 \mathrm{HR}$. Treatments 1 and 2 were applied to five seedlings each which were $\mathrm{N}$ deficient and to five $\mathrm{N}$ sufficient seedlings, whereas treatments 3,4 , and 5 were applied to only $\mathrm{N}$ sufficient single leaves on both surfaces. The ${ }^{15} \mathrm{~N}$ source, the amount applied per leaf, and application technique were similar to that in Expt. 2.

Analysis of ${ }^{15} \mathrm{~N} .{ }^{15} \mathrm{~N}$ treated leaves from the greenhouse and field studies were surfacecleaned with cellulose acetate, dried, and ground to a powder in a Wiley mill to pass through a $1-\mathrm{mm}$ sieve. Total $\mathrm{N}$ was determined from a $0.2 \mathrm{~g}$ sample by the permanganate-reduced Fe modification of the semi-micro-
Kjeldahl procedure (Bremner and Mulvaney, 1982). The distillation apparatus was cleaned following each sample by the duplicate aliquot procedure (Mulvaney, 1986) to prevent ${ }^{15} \mathrm{~N}$ cross-contamination. Distillates were evaporated to dryness for ${ }^{15} \mathrm{~N}$ analysis and atom $\%{ }^{15} \mathrm{~N}$ was determined at the Univ. of Illinois on a Nucleide 3-60-RMS double collector mass spectrometer (Measurement and Analysis Systems, Belefonte, Pa.) according to procedures described by Mulvaney (1986). Percentage of ${ }^{15} \mathrm{~N}$ absorption was calculated from the fertilizer ${ }^{15} \mathrm{~N}$ recovered (FNR, corrected for natural abundance of ${ }^{15} \mathrm{~N}$, Wilson et al., 1990), divided by the amount of fertilizer $\mathrm{N}$ applied multiplied by 100 .

The ${ }^{15} \mathrm{~N}$ data were tested for significant differences $(P<0.05)$ using a $2 \mathrm{~N}$ levels $\times 2$ surfaces $\times 2$ time of day or by $1 \mathrm{~N}$ level $\times 3$ time of day factorial ANOVA with five replications and Duncan's multiple range test to separate means.

Experiment 4. Greenhouse study of longterm fate of foliar urea applications. In order to determine the long-term fate on $\mathrm{N}$ absorption, liquid urea and Triazone-urea solutions were sprayed (one application) to leaves and sampled at different intervals over an 8-week period. Eight, 2-year-old trees of 'Duncan' grapefruit (Citrus paradisi L. Macf.) on rough lemon (C.jambhiri Lush) rootstock were grown in $10-\mathrm{L}$ pots of sand in an unshaded glasshouse. Trees were well nourished with a complete fertilizer (20:20:20) and well-watered between fertilizations. The treatments consisted of: 1) no foliar spray (control); 2) foliar spray of liquid urea; and 3) foliar spray of Triazone-urea. All urea solutions contained $0.5 \%$ Triton-X77 (v/v) as a surfactant. The experimental design was a randomized block with 8 replicated trees with each tree having all three treatments on different branches. All foliar sprays were based on the rate of $34 \mathrm{~kg}$ $\mathrm{N} / \mathrm{ha}$ in $469 \mathrm{~L}$ of water and sprayed to run off from both surfaces with a small hand sprayer. The trees were not fertilized after foliar applications. All applications were made onto the spatially- separated branches of the 8 replicate trees between $0800 \mathrm{HR}$ to $1000 \mathrm{HR}$ in an isolated area of the greenhouse to prevent cross contamination. After foliar urea applications, 2-4 leaves from each branch on each of the 8 trees were sampled at 0.5-, 1-, 2-, 4-, and 8-week intervals for total $\mathrm{N}$ analysis. The harvested leaves were washed with distilled water and oven-dried at $70{ }^{\circ} \mathrm{C}$ for $48 \mathrm{~h}$. The dried leaf

Table 1. Experiment 1. Effect of urea formulations of foliar-applied fertilizer on leaf $\mathrm{N}$ concentration of grapefruit during fall $(\mathrm{F})$ and summer $(\mathrm{S})$ seasons. $^{2}$

\begin{tabular}{|c|c|c|c|c|c|c|c|c|}
\hline \multirow{3}{*}{ Treatment } & \multicolumn{8}{|c|}{ Leaf age (months) } \\
\hline & \multicolumn{2}{|c|}{0.25} & \multicolumn{2}{|c|}{1} & \multicolumn{2}{|c|}{3} & \multicolumn{2}{|c|}{6} \\
\hline & F 1994 & S 1995 & F 1994 & S 1995 & F 1994 & S 1995 & F 1994 & S 1995 \\
\hline & $-\ldots$ & $--\ldots$ & --- & $-\% \mathrm{~N}$ & $-\ldots$ & --- & ---- & $-\ldots$ \\
\hline Control & $\overline{1.58} \overline{\mathrm{b}}$ & $1 . \overline{5} 5 \bar{b}$ & $1.96 \mathrm{~b}$ & $\overline{2} .01 \mathrm{~b}$ & $1 . \overline{95} \mathrm{~b}$ & $2.08 \mathrm{~b}$ & $1.98 \mathrm{~b}$ & $2.01 \mathrm{~b}$ \\
\hline \multirow[t]{2}{*}{ Urea $^{y}$} & $2.10 \mathrm{a}$ & $2.07 \mathrm{a}$ & $2.49 \mathrm{a}$ & $2.46 \mathrm{a}$ & $2.24 \mathrm{a}$ & $2.32 \mathrm{a}$ & $2.17 \mathrm{a}$ & $2.18 \mathrm{a}$ \\
\hline & S 1996 & F 1996 & S 1996 & F 1996 & S 1996 & F 1996 & S 1996 & F 1996 \\
\hline Control & $1.90 \mathrm{~b}$ & $1.95 \mathrm{~b}$ & $2.01 \mathrm{~b}$ & $2.10 \mathrm{~b}$ & $2.10 \mathrm{~b}$ & $2.12 \mathrm{~b}$ & $1.95 \mathrm{~b}$ & $2.05 \mathrm{~b}$ \\
\hline Urea $^{y}$ & $2.43 \mathrm{a}$ & $2.38 \mathrm{a}$ & $2.35 \mathrm{a}$ & $2.39 \mathrm{a}$ & $2.36 \mathrm{a}$ & $2.36 \mathrm{a}$ & $2.21 \mathrm{a}$ & $2.22 \mathrm{a}$ \\
\hline
\end{tabular}

${ }^{\mathrm{z}}$ Means within a column of a season followed by the same letter are not significantly different at $P \leq 0.05$. ${ }^{y}$ Average leaf $\mathrm{N}$ concentration from liquid-urea, Triazone-urea, and spray grade urea applied at the rate of $34 \mathrm{~kg} \cdot \mathrm{ha}^{-1} \mathrm{~N}$. 
tissue was ground to a powder and analyzed for total N using semi-micro-Kjeldahl method.

Experiment 5. Field study. The 8-week greenhouse study described above was duplicated using bearing trees in the field during Summer 1996. Eight 10-year-old trees of 'Duncan' grapefruit (Citrus paradisi Macf.) on rough lemon ( $C$. jambhiri Lush) rootstock were used for this study. Standard horticultural practices were carried out to maintain healthy trees during the course of the study. The treatments, experimental design, foliar spray techniques, and total $\mathrm{N}$ analysis were same as in the greenhouse study.

\section{Results}

Experiment 1. Leaf age and urea formulation. Foliar urea applications significantly increased $\mathrm{N}$ concentration over the control within each leaf-age group (Table 1). There were no significant differences among different formulations of urea spray. Thus, an average leaf $\mathrm{N}$ concentration from the three urea formulations is presented in Table 1 . The young leaves ( 0.25 and 1 month old) exhibited greater $\mathrm{N}$ absorption efficiency than the old leaves ( 3 and 6 month old) in both seasons. However, the reduction in leaf $\mathrm{N}$ absorption with leaf age was not quantified.

Experiment 2. Leaf age, $\mathrm{N}$ status, epicuticular wax, and ${ }^{15} \mathrm{~N}$-urea absorption. Mature citrus leaves are considered as $\mathrm{N}$ deficient if their $\mathrm{N}$ concentration is $<2.2 \%$ and $\mathrm{N}$ sufficient if their $\mathrm{N}$ concentrations is more than $2.5 \%$ (Tucker et al., 1995). In N-deficient leaves $(1.80 \% \mathrm{~N}), 0.25$-month-old leaves exhibited greatest ${ }^{15} \mathrm{~N}$ recovery $(49 \%)$, followed by 1 -month-old (38\%), 3-month-old (30\%), and 6-month-old (27\%) leaves (Fig. 1). The $\mathrm{N}$ sufficient leaves $(2.60 \% \mathrm{~N})$ exhibited a similar decreasing trend with $0.25-, 1-, 3-$, and 6-month-old leaves recovering 66\%, 57\%, $50 \%$, and $45 \%$ of ${ }^{15} \mathrm{~N}$, respectively (Fig. 1). The $\mathrm{N}$-sufficient leaves absorbed more ${ }^{15} \mathrm{~N}$ than $\mathrm{N}$-deficient leaves.

Chloroform extracts of wax from leaves of different ages indicated that epicuticular wax concentration increased with leaf age in both $\mathrm{N}$-deficient and N-sufficient leaves (Fig. 1). The cuticle weight also increased with leaf age under both $\mathrm{N}$ levels (Table 2). Within each leaf-age group, the adaxial cuticles were heavier than abaxial cuticles regardless of $\mathrm{N}$ level. The cuticle weights of $\mathrm{N}$-deficient leaves tended to be greater than the cuticle weights of $\mathrm{N}$-sufficient leaves, but were not significantly different (Table 2).

Experiment 3. Diurnal ${ }^{15} \mathrm{~N}$ absorption by adaxial and abaxial leaf surfaces. The abaxial surfaces of both $\mathrm{N}$-deficient and $\mathrm{N}$-sufficient leaves absorbed more ${ }^{15} \mathrm{~N}$ than adaxial surfaces (Table 3). When ${ }^{15} \mathrm{~N}$ was applied between $0800 \mathrm{HR}$ and $1000 \mathrm{HR}$, the adaxial surfaces of $\mathrm{N}$ deficient leaves $(1.20 \% \mathrm{~N}$, a low $\mathrm{N}$ concentration but leaves were photosynthetically active, $6 \mu \mathrm{mol} \cdot \mathrm{m}^{-2} \cdot \mathrm{s}^{-1} \mathrm{CO}_{2}$ ) absorbed $43 \%$ of the applied ${ }^{15} \mathrm{~N}$ compared to $48 \%$ from the abaxial surface. The $\mathrm{N}$-sufficient leaves $(2.65 \% \mathrm{~N})$ absorbed $49 \%$ and $55 \%$ of the applied ${ }^{15} \mathrm{~N}$ via adaxial and abaxial surfaces,

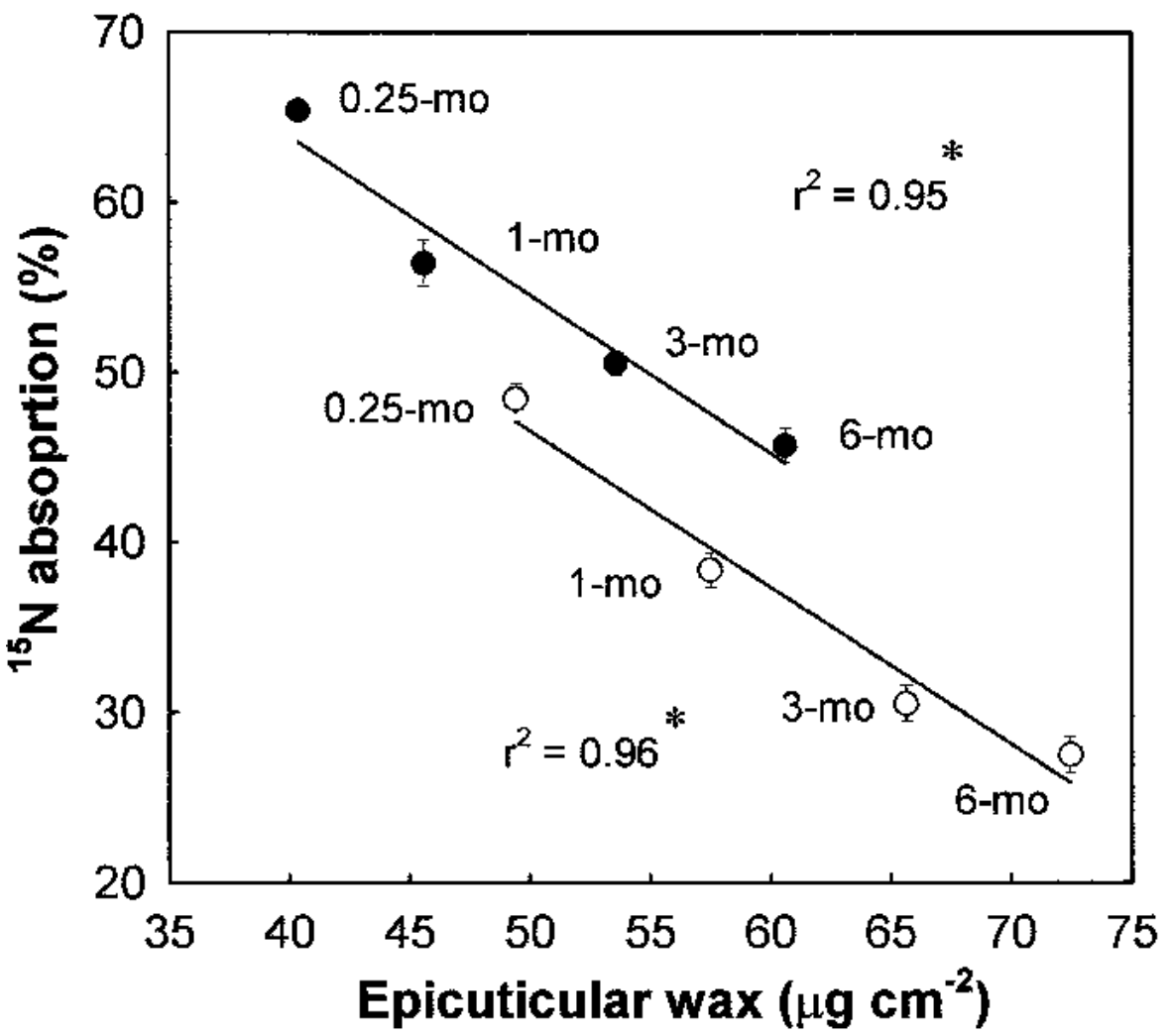

Fig. 1. Relationships between ${ }^{15} \mathrm{~N}$ absorption and epicuticular wax of leaves of four leaf age groups $(\mathrm{n}=5)$ from $\mathrm{N}$ deficient $\left(1.80 \%\right.$ leaf $\left.\mathrm{N}, \mathrm{O}, \mathrm{y}=92-91 \mathrm{x}, r^{2}=0.96\right)$ and $\mathrm{N}$ sufficient $(2.60 \%$ leaf $\mathrm{N}, \boldsymbol{O}, \mathrm{y}=101$ $\left.-93 \mathrm{x}, r^{2}=0.95\right)$ of 'Hamlin' orange trees. The intercepts of regression equations for $\mathrm{N}$ deficient and $\mathrm{N}$ deficient leaves were significantly different at $P \leq 0.05$ as indicated by students $t$ test. Each point represents a mean of five leaves. Bars indicate \pm SE. If no bar is shown, the SE is within the dimension of the symbol.

Table 2. Experiment 2. Effect of leaf age on cuticle weights in $\mathrm{N}$ deficient $(1.80 \%$ $\mathrm{N})$ and $\mathrm{N}$ sufficient leaves $(2.60 \% \mathrm{~N})$ of 'Hamlin' orange $(\mathrm{n}=4)$.

\begin{tabular}{|c|c|c|c|c|c|c|}
\hline \multirow{2}{*}{$\begin{array}{l}\text { Leaf age } \\
\text { (months) }\end{array}$} & \multicolumn{3}{|c|}{$\mathrm{N}$ deficient } & \multicolumn{3}{|c|}{$\mathrm{N}$ sufficient } \\
\hline & Adaxial & Abaxial & Total & Adaxial & Abaxial & Total \\
\hline & ---- & --- & --- & $-2 \cdot--$ & ---- & $\overline{---}$ \\
\hline 0.25 & $207 \mathrm{c}$ & $191 \mathrm{c}$ & $398 \mathrm{c}$ & $192 \mathrm{c}$ & $180 \mathrm{c}$ & $372 \mathrm{c}$ \\
\hline 1 & 292 b & $279 \mathrm{~b}$ & $571 \mathrm{~b}$ & $280 \mathrm{~b}$ & $268 \mathrm{~b}$ & $548 \mathrm{~b}$ \\
\hline 3 & $471 \mathrm{a}$ & $459 \mathrm{a}$ & $930 \mathrm{a}$ & $460 \mathrm{a}$ & $445 \mathrm{a}$ & $905 \mathrm{a}$ \\
\hline 6 & $487 \mathrm{a}$ & $467 \mathrm{a}$ & $954 \mathrm{a}$ & $478 \mathrm{a}$ & $457 \mathrm{a}$ & $935 \mathrm{a}$ \\
\hline
\end{tabular}

Means within a column followed by the same letter are not significantly different at $P \leq 0.05$.

respectively. ${ }^{15} \mathrm{~N}$ application at night increased the amount absorbed by adaxial and abaxial leaf surfaces by both $\mathrm{N}$-deficient and $\mathrm{N}$ sufficient leaves. The N-sufficient leaves absorbed a significantly greater amount of ${ }^{15} \mathrm{~N}$ through either surface than $\mathrm{N}$-deficient leaves regardless of the time of application. Foliar ${ }^{15} \mathrm{~N}$-urea application in $\mathrm{N}$ sufficient leaves between $1200 \mathrm{HR}$ and $1400 \mathrm{HR}$ resulted in ${ }^{15} \mathrm{~N}$ absorption of only $40 \%$ (Table 3 ). The ${ }^{15} \mathrm{~N}$ absorption between $2000 \mathrm{HR}$ to $2200 \mathrm{HR}$ was significantly greater than ${ }^{15} \mathrm{~N}$ absorption either during $0800 \mathrm{HR}$ to $1000 \mathrm{HR}$ or $1200 \mathrm{HR}$ to $1400 \mathrm{HR}$. The minimum temperature and maximum relative humidity $(\mathrm{RH})$ were $21^{\circ} \mathrm{C}$ and $90 \%$ during the night period. In the morning, the temperature rose to $27^{\circ} \mathrm{C}$, the $\mathrm{RH}$ declined to $35 \%$, and by the afternoon, the maximum temperature was $35^{\circ} \mathrm{C}$ with a $\mathrm{RH}$ of $70 \%$.
Experiment 4. Long-term foliar urea application. There was a remarkable effect of different time intervals and different urea sprays on $\mathrm{N}$ absorption by leaves sampled in the greenhouse and in the field (Fig. 2). One to 2 weeks after urea applications, leaves sprayed with either liquid urea or Triazone-urea had significantly greater $\mathrm{N}$ levels than the controls but the $\mathrm{N}$ levels $(\%)$ were not different between liquid urea and Triazone-urea sprayed leaves. After 4 weeks, $\mathrm{N}$ levels of leaves sprayed with liquid urea remained similar to the unsprayed controls until the end of the sampling period in both studies. In contrast, 4 weeks (greenhouse study, Fig. 2A) and 8 weeks (field study, Fig. 2B) after the urea applications, leaves sprayed with Triazone-urea maintained significantly greater $\mathrm{N}$ concentrations than either control or liquid urea sprayed leaves. 
Table 3. Experiment 3. Diurnal ${ }^{15} \mathrm{~N}$ absorption by adaxial and abaxial surfaces of $\mathrm{N}-$ deficient leaves, $\mathrm{N}$-sufficient leaves and both surfaces of $\mathrm{N}$-sufficient leaves of 'Cleopatra' mandarin trees. $(n=5)$.

\begin{tabular}{lcccccc}
\hline \hline & \multicolumn{2}{c}{$\mathrm{N}$ deficient } & & \multicolumn{2}{c}{ N sufficient } & \\
\cline { 2 - 3 } $\begin{array}{l}\text { Application } \\
\text { time }\end{array}$ & $\begin{array}{c}\text { Adaxial } \\
\text { surface }\end{array}$ & $\begin{array}{c}\text { Abaxial } \\
\text { surface }\end{array}$ & & $\begin{array}{c}\text { Adaxial } \\
\text { surface }\end{array}$ & $\begin{array}{c}\text { Abaxial } \\
\text { surface }\end{array}$ & $\begin{array}{c}\text { Both } \\
\text { surfaces }\end{array}$ \\
\hline $\begin{array}{l}\%^{15} \mathrm{~N} \text { absorption } \\
0800 \mathrm{HR} \text { to } 1000 \mathrm{HR}\end{array}$ & $43 \mathrm{~b}^{\mathrm{z}}$ & $48 \mathrm{~b}$ & & $49 \mathrm{~b}$ & $55 \mathrm{~b}$ & $50 \mathrm{c}^{\mathrm{y}}$ \\
$1200 \mathrm{HR}$ to $1400 \mathrm{HR}$ & & & & & & \\
$2000 \mathrm{HR}$ to $2200 \mathrm{HR}$ & $47 \mathrm{a}$ & $54 \mathrm{a}$ & & $54 \mathrm{a}$ & $62 \mathrm{a}$ & $55 \mathrm{a}$ \\
\hline
\end{tabular}

${ }^{\mathrm{z}}$ Means within a column followed by the same letter are not significantly different at $P \leq 0.05$.

y Indicates ${ }^{15} \mathrm{~N}$ absorption by whole leaves (both leaf surfaces).
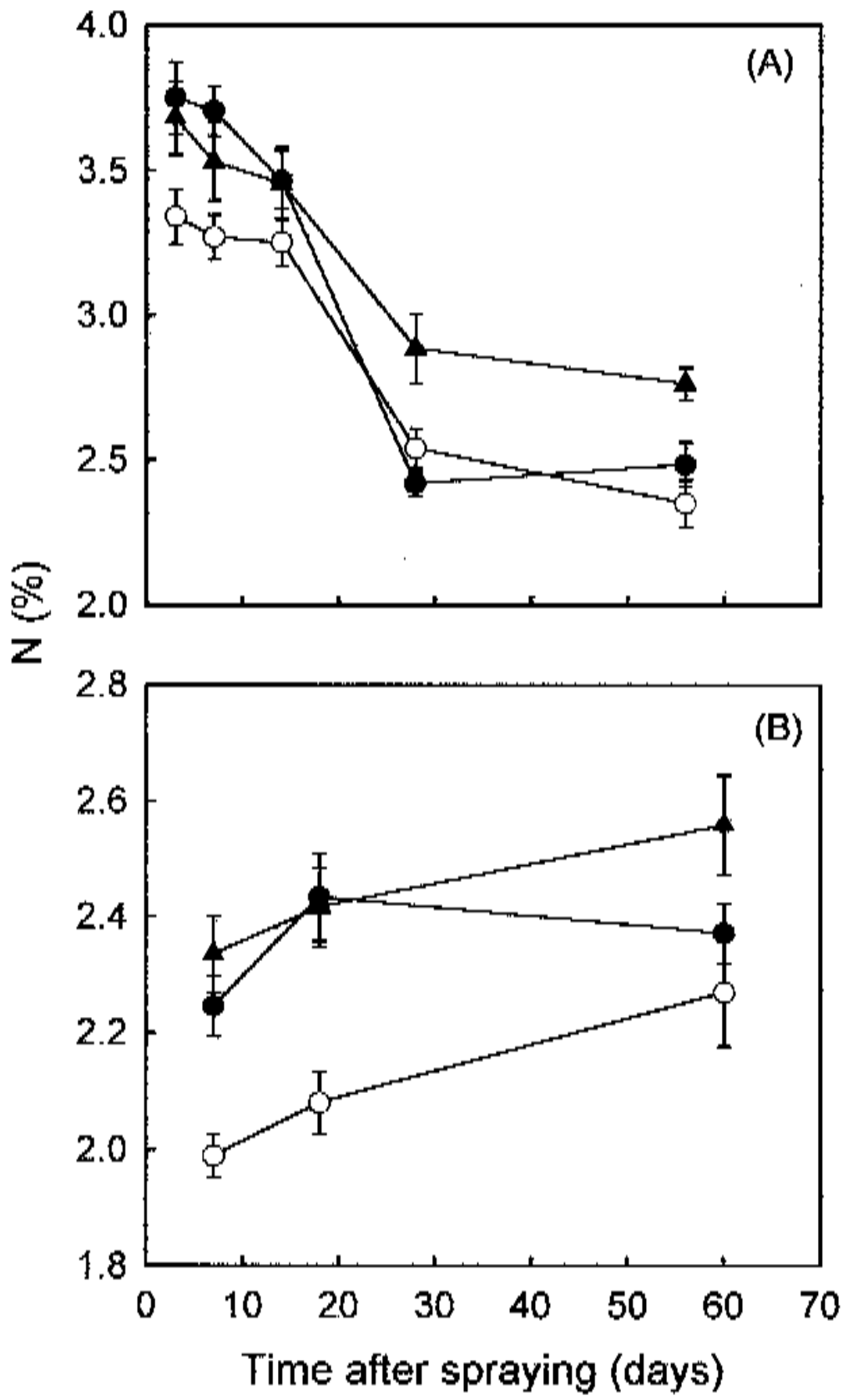

Fig. 2. Effect of urea formulation and time after application on $\mathrm{N}$ concentration of 'Duncan' grapefruit leaves grown in (A) greenhouse $(\bigcirc$ control, Unocal Plus-urea, and $\boldsymbol{\Delta}$ Triazone-urea) and $(\mathbf{B})$ field $(\bigcirc$ control, Unocal Plus- urea, and $\mathbf{\Delta}$ Triazone-urea). Each point represents the mean of 8 replicate trees. Bars indicate $\pm \mathrm{SE}$.

\section{Discussion}

Leaf age, urea formulations, and ${ }^{15} \mathrm{~N} a b$ sorption. Although foliar-applied urea significantly increased leaf $\mathrm{N}$ concentration (Table 1), $\mathrm{N}$ absorption declined with leaf age as indicated by ${ }^{15} \mathrm{~N}$ study (Fig. 1). The decline in ${ }^{15} \mathrm{~N}$-urea absorption with leaf age was consistent with previous studies in citrus (Lea-Cox and Syvertsen, 1995), cotton (Bondada et al., 1997), apple (Khemira et al., 1999), coffee, cacao, and banana (Cain, 1956).

As leaves aged, epicuticular wax increased which correlated negatively with ${ }^{15} \mathrm{~N}$ absorption in both $\mathrm{N}$-deficient $(1.80 \% \mathrm{~N})$ and $\mathrm{N}$ sufficient $(2.60 \% \mathrm{~N})$ leaves. Leece (1976) observed similar results which indicated that surface wax concentration correlated well with resistance to foliar-absorption of urea-N. In addition to strong negative relationships between epicuticular wax and ${ }^{15} \mathrm{~N}$ absorption, the decline in ${ }^{15} \mathrm{~N}$ absorption with increasing epicuticular wax was probably associated with qualitative changes in wax composition with leaf age in both $\mathrm{N}$ regimes. The chemical properties of surface wax determine the efficiency of foliar-applied chemicals (Holloway, 1969). The epicuticular wax of citrus leaves is predominantly constituted of hydrocarbons (alkanes, $23 \%$ to $66 \%$ ), the most hydrophobic component of the epicuticular wax that increases with leaf age (Baker et al., 1975).

Nitrogen deficiency induced an increase in epicuticular wax concentration that was greater than the epicuticular wax concentration of $\mathrm{N}$ sufficient leaves (Fig. 1). An analogous response was observed in Pinus palustris needles with low $\mathrm{N}$ needles exhibiting greater epicuticular wax concentration than high $\mathrm{N}$ needles (Prior et al., 1997). Although, we did not measure leaf expansion characteristics, $\mathrm{N}$ deficiency may have reduced leaf expansion resulting in smaller leaves with thicker cuticles and more epicuticular wax. The low ${ }^{15} \mathrm{~N}$ absorption of $\mathrm{N}$-deficient leaves could also have been due to increased wax concentration with presumably high levels of long chain alkanes stimulated by $\mathrm{N}$ deficiency since $\mathrm{N}$ fertilization changed epicuticular wax morphology in Douglas fir (Chiu et al., 1992).

Diurnal ${ }^{15} \mathrm{~N}$ absorption by surfaces of leaves. Abaxial surfaces had greater ${ }^{15} \mathrm{~N}$ absorption than adaxial surfaces (Table 3 ). Since citrus leaves are hypostomatous, it is possible that urea may have entered through the abaxial stomata. This was unlikely however, since abaxial absorption of ${ }^{15} \mathrm{~N}$ during the dark was greater than adaxial absorption despite presumably closed stomata (Table 3 ). Thus, the greater ${ }^{15} \mathrm{~N}$ absorption by abaxial than adaxial surfaces was more likely due to the thinner (lower weight) cuticles (Table 2). The greater urea absorption during night also may have been due to lower night time temperatures and higher humidities resulting in less evaporative losses, volatilization losses, or both, than during the morning or afternoon periods (Table 3).

Long-term urea applications. One week after the three weekly sprays of liquid urea or Triazone-urea, $\mathrm{N}$ absorption by the leaves 
from different urea formulations was not significantly different in either season (Table 1). However, 4 and 8 weeks after spray application, leaves sprayed with Triazone-urea had greater $\mathrm{N}$ concentrations than control and liquid urea sprayed leaves (Fig. 2). The persistence of elevated $\mathrm{N}$ by Triazone-urea may come from its ability to metabolize less quickly than the conventional urea (Clapp, 1991). Also, the spray droplets of Triazone-urea remain on the leaf surface in a liquid phase for an extended period of time. Kissel and Cabrera (1988) reported that volatilization loss of conventional urea $\mathrm{N}$ from the surface of grass leaves was four-fold greater than that from Triazone-urea. Hence, Triazone-urea could be a more efficient form of $\mathrm{N}$ to apply to citrus leaves since a single application of Triazoneurea could reduce the need for multiple applications of conventional urea.

In summary, $\mathrm{N}$ absorption declined with leaf age. The decline in $\mathrm{N}$ absorption with leaf age was correlated with increased epicuticular wax. $\mathrm{N}$ deficient leaves had lower $\mathrm{N}$ absorption than $\mathrm{N}$ sufficient leaves. Night time application resulted in a greater $\mathrm{N}$ absorption by leaves than either morning or afternoon application. Leaves sprayed with Triazone-urea maintained a greater $\mathrm{N}$ concentration than leaves sprayed with liquid urea for up to eight weeks. $\mathrm{N}$ absorption was greatest through abaxial surfaces of young leaves with sufficient $\mathrm{N}(2.60 \% \mathrm{~N})$, low epicuticular wax, and relatively thin cuticles.

\section{Literature Cited}

Ali, A.G. and C.J. Lovatt. 1994. Winter application of low-biuret urea to the foliage of 'Washington' Navel orange increased yield. J. Amer. Soc. Hort. Sci. 119:1144-1150.

Baker, E.A., J. Procopiou, and G.C. Hunt. 1975. The cuticles of citrus species. Composition of leaf and fruit waxes. J. Sci. Food Agr. 26:10931101.

Bondada, B.R., D.M. Oosterhuis, and R.J. Norman. 1997. Cotton leaf age, epicuticular wax, and nitrogen-15 absorption. Crop Sci. 37:807-811.

Bowman, D.C. and K.L. Paul. 1992. Foliar absorption of urea, ammonium, and nitrate by perennial ryegrass turf. J. Amer. Soc. Hort. Sci. 117:75-79.
Bremner, J.M. and C.S. Mulvaney. 1982. NitrogenTotal, p. 595-694. In: A.L. Page et al. (eds.). Methods of soil analysis. Part 2. $2^{\text {nd }}$ ed. Agron. Monogr. 9 ASA and SSSA, Madison, Wis.

Cain, J.C. 1956. Absorption and metabolism of urea by leaves of coffee, cacao, and banana. Proc. Amer. Hort. Sci. 67:279-286.

Chiu, S., L.H. Anton., F.W. Ewers, R. Hammerschmidt, and K.S. Pregitzer. 1992. Effects of fertilization on epicuticular wax morphology of needles leaves of Douglas Fir, Pseudotsuga Menziesii (Pinaceae). Amer. J. Bot. 79:149-154.

Clap Jr., J.G. and T.M. Parham. 1991. Properties and uses of liquid urea-triazone based nitrogen fertilizers. Fert. Res. 28:229-232.

Cook, J.A. and J. Boynton. 1952. Some factors affecting the absorption of urea by McIntosh apple leaves. Proc. Amer. Soc. Hort. Sci. 59:82-90.

Council for Agricultural Science and Technology. 1985. Agriculture and ground water quality. Council Agr. Sci. Technol. Ret. 103.

Embleton, T.W. and W.W. Jones. 1974. Foliarapplied nitrogen for citrus fertilization. J. Environ. Qual. 13:353-356.

Holloway, P.J. 1969. Chemistry of leaf waxes in relation to wetting. J. Sci. Food Agr. 20:124128.

Impey, R.L. and W.W. Jones. 1960. Rate of absorption of urea by intact leaves of Washington navel orange. Proc. Amer. Soc. Hort. Sci. 76:181185.

Khemira, H., T.L. Righetti, and A.N. Azarenko. 1998. Nitrogen partitioning in apple as affected by timing and tree growth habit. J. Hort. Sci. Biotech. 73:217-223.

Khemira, H., T.L. Righetti, and A.N. Azarenko. 1999. Distribution of urea-derived nitrogen supplied to apple leave. Hort. Sci. 34:1079-1081.

Kissel, D.E. and M.L. Cabrera. 1988. Ammonia volatilization from urea and an experimental thiazine fertilizer. HortScience 23:1087.

Knoche, M., P.D. Petracek, and M.J. Bukovac. 1994. Urea penetration of isolated tomato fruit cuticles. J. Amer. Soc. Hort. Sci. 119:761-764.

Lea-Cox, J.D. and J.P. Syvertsen. 1995. Nitrogen uptake by citrus leaves. J. Amer. Soc. Hort. Sci. 120:505-509.

Leece, D.R. 1976. Composition and ultrastructure of leaf cuticles from fruit trees relative to differential foliar absorption. Aust. J. Plant Physiol. 3:833-847.

MacKay, D.M. and L.A. Smith. 1990. Agricultural chemicals in groundwater: Monitoring and management in California. J. Soil Water Conserv. $45: 253-255$.
Mulvaney, R.L. 1986. Comparisons of procedures for reducing cross-contamination during steam distillation in nitrogen $-{ }^{15} \mathrm{~N}$ tracer research. Soil Sci. Soc. Amer. J. 50:92-96.

Noris, R.F. and M.J. Bukovac. 1972. Influence of cuticular waxes on penetration of pear leaf cuticle by 1-naphthaleneacetic acid. Pest. Sci. 3:705-708.

Orgell, W.H. 1955. The isolation of plant cuticle with pectic enzymes. Plant Physiol. 30:78-80.

Prior, S.P., S.G. Pritchard, G.B. Runion, H.G. Rogers, and R.J. Mitchell. 1997. Influence of atmospheric $\mathrm{CO}_{2}$ enrichment, soil nitrogen, and water stress on needle surface wax formation in Pinus palustris (Pinaceae). Amer. J. Bot. 84:1070-1077.

Riotte, W. 1994. Ridge citrus water quality project manual (1993) report. Florida Dept. Agr. Consum. Serv., Tallahassee.

Romero-Aranda, R. and J.P. Syvertsen. 1996. The influence of foliar-applied urea nitrogen and saline solutions on net gas exchange of citrus leaves. J. Amer. Soc. Hort. Sci. 121:501-506.

Swietlik, D., and M. Faust. 1984. Foliar nutrition of fruit crops, p. 287-355. In: Horticulture Reviews, Vol. 6. J. Janick (ed.). AVI Publishing Co., Westport, Conn.

Tucker, D.P.H., A.K. Alva, L.K. Jackson, and T.A. Wheaton. 1995. Nitrogen fertilization. In: D.P.H. Tucker, A.K. Alva, L.K. Jackson, T.A. Wheaton (eds.). Coop. Ext. Serv., Univ. of Florida, SP 169.

van der Voet, E., R.K. Kleijn, and H.A. Udo de Haes. 1996. Nitrogen pollution in the European union-origins and proposed solutions. Environ. Conserv. 23:120-132.

Weinbaum, S.A. 1988. Foliar nutrition of fruit trees, p. 81-100. In:P.M. Neumann (ed.). Plant Growth and leaf-applied chemicals. CRC Press, Boca Raton, Fla.

Wilson, C.E., R.J. Norman, and B.R. Wells. 1990. Dicyandiamide influence on uptake of pre-plant applied fertilizer nitrogen by rice. Soil Sci. Soc. Amer. J. 54:1157-1161.

Wittwer, S.H., M.J. Bukovac, and H.B. Tukey. 1963. Advances in foliar feeding of plant nutrients, $p$. 429-455. In: M.H. McVickar, G.L. Bridger, and L.B. Nelson (eds.). Fertilizer technology and usage. Amer. Soc. Agron. Madison, Wis.

Yamada, Y., W.H. Jyung, S.H. Wittwer, and M.J. Bukovac. 1965. Effect of urea on ion penetration through isolated cuticular membranes. Plant Physiol. 39:978-982.

Zhu, B. 1989. The absorption and translocation of foliar-applied nitrogen in cotton. M.S. Thesis, Univ. of Arkansas, Fayetteville. 